\title{
TATA KELOLA DAN RISIKO BANK SYARIAH DI INDONESIA \\ PERIODE 2008-2016
}

\author{
Siti Mutmainah \\ Departemen Akuntansi Fakultas Ekonomika dan Bisnis Universitas Diponegoro
}

\begin{abstract}
This study investigates the effect of corporate governance on Islamic bank's risk in Indonesia during 2008-2016. The bank's governance consists of board of commissioner (including risk control committe and audit committee), management, and sharia supervisory board. Because of the existence of these boards is a mandatory, hence this research focus on the amount of members and meetings in each board and committee. Results show that the amount of meetings held by management and risk control committee negatively influence the financing risk. This research implies the Islamic banks to strenghten their governance to control their banks' risk. This research also recommends Central Bank and National Sharia Board to be more effective in performing its supervisory function.
\end{abstract}

Keywords: corporate governance, financing risk, Islamic Bank.

\section{PENDAHULUAN}

Risiko dan imbal hasil (return) bank merupakan hal-hal yang menjadi pertimbangan nasabah dalam menginvestasikan dananya di bank, termasuk nasabah bank syariah. Skema uncertainty contract pada bank syariah yaitu pada transaksi-transaksi investasi (misalnya pada akad mudharabah dan musyarakah), mengarahkan kepada perolehan imbal hasil yang tidak pasti dan tidak tetap. Konsep investasi tersebut adalah usaha yang menanggung risiko. Hal ini berarti pada setiap kesempatan memperoleh keuntungan dari usaha yang dilaksanakan, pada saat yang sama terdapat pula risiko untuk menerima kerugian. Oleh karena itu antara nasabah atau deposan dan bank sama-sama saling berbagi baik keuntungan maupun risiko, atau yang lebih dikenal dengan istilah bagi hasil (profit-loss sharing).

$$
\text { Berdasarkan Laporan }
$$

Perkembangan Keuangan Syariah (LPPS) 2016 diketahui bahwa penyaluran pembiayaan perbankan syariah masih didominasi oleh piutang murabahah yakni sebesar 56,78\%, diikuti oleh penyaluran pembiayaan musyarakah sebesar 31,10\%. Dalam jumlah yang kecil, penyaluran 
pembiayaan syariah dialokasikan pada pembiayaan berbasis akad mudharabah, ijarah, qardh, dan istishna masingmasing sebesar 6,07\%; 3,60\%; 1,91\%, dan $0,35 \%$. Walaupun porsi penyaluran pembiayaan berbasis bagi hasil (musyarakah dan mudharabah) masih lebih kecil dibandingkan penyaluran pembiayaan berbasis jual beli (murabahah), tren perkembangannya semakin meningkat dari tahun ke tahun. Hal ini mengindikasikan bahwa bank syariah secara bertahap telah mampu memitigasi risiko penyaluran pembiayaan berbasis bagi hasil dan mulai mengurangi ketergantungan pada penyaluran pembiayaan berbasis jual beli. Selain hal tersebut, diketahui bahwa kualitas pembiayaan 2016 (NPF gross $4,15 \%$ dan NPF net sebesar 2,06\%) membaik dibandingkan tahun 2015 (NPF gross dan net masing-masing sebesar 4,34\% dan 2,77\%). Secara nominal jumlah non-performing mencapai $\mathrm{Rp}$ 10,5 triliun pada tahun 2016.

Perkembangan lingkungan yang semakin pesat menyebabkan risiko usaha yang dihadapi perbankan syariah juga semakin kompleks. Oleh karenanya manajemen risiko merupakan hal yang sangat penting dalam entitas perbankan.
Menurut Peraturan Bank Indonesia Nomor 13/23/PBI/2011 tentang Penerapan Manajemen Risiko Bagi Bank Umum Syariah dan Unit Usaha Syariah, risiko yang dihadapi perbankan syariah mencakup sepuluh risiko, yaitu risiko kredit, risiko pasar, risiko likuiditas, risiko operasional, risiko hukum, risiko reputasi, risiko strategik, risiko kepatuhan, risiko imbal hasil dan risiko investasi. Sebelum peraturan tersebut berlaku, manajemen risiko perbankan syariah mengikuti manajemen risiko bagi perbankan konvensional yang mencakup delapan risiko, selain risiko imbal hasil dan risiko investasi.

Perbankan syariah dituntut mampu mengelola risiko yang dihadapi berdasarkan dua ketentuan sekaligus yaitu ketentuan syariah maupun ketentuan perbankan. Karena kondisi bank syariah yang beragam, maka penerapan manajemen risiko pada perbankan syariah disesuaikan dengan ukuran dan kompleksitas usaha serta kemampuan bank. Tata kelola bank (corporate governance) diindikasikan sebagai salah satu hal yang berperan penting dalam menentukan tingkat risiko yang dihadapi oleh bank, yang pada akhirnya berimbas pada imbal hasil. 
Tata kelola yang baik merupakan salah satu upaya untuk melindungi kepentingan stakeholder dan meningkatkan kepatuhan terhadap peraturan perundang-undangan yang berlaku serta nilai-nilai etika yang berlaku secara umum pada industri perbankan syariah. Berdasar Peraturan Bank Indonesia Nomor 13/23/PBI/2011 Pasal 3 diketahui bahwa pengawasan aktif dari Dewan Komisaris, Direksi, dan Dewan Pengawas Syariah merupakan salah satu unsur penerapan manajemen risiko perbankan syariah. Komponen lain menurut ketentuan tersebut adalah kecukupan kebijakan, prosedur, dan penetapan limit manajemen risiko; kecukupan proses identifikasi, pengukuran, pemantauan, dan pengendalian risiko serta sistem informasi manajemen risiko; dan sistem pengendalian intern yang menyeluruh.

Penelitian ini menguji pengaruh tata kelola perbankan syariah terhadap risiko yang dihadapi bank syariah. Tata kelola perbankan syariah yang akan ditelaah mencakup atribut-atribut Dewan Komisaris, Direksi, Dewan Pengawas Syariah, Komite Pemantau Risiko, dan Komite Audit. Atribut yang diteliti (meliputi jumlah anggota dan jumlah pertemuan dalam setahun) menjadi proksi efektivitas organ tersebut di perusahaan. Dalam penelitian ini, risiko perbankan syariah yang akan ditelaah difokuskan pada risiko pembiayaan.

Arunkumar dan Kotreshwar (2005) menemukan bahwa risiko kredit memberi kontribusi sebesar $70 \%$ pada total risiko yang dihadapi bank. Basel Committee, badan pengawas perbankan internasional juga mengklaim bahwa sumber terbesar bagi permasalahan serius yang dihadapi bank adalah risiko kredit. Hal ini diperkuat oleh LPPS 2016 yang menyatakan bahwa risiko yang secara signifikan mempengaruhi profil risiko bank syariah secara keseluruhan adalah risiko kredit dan risiko operasional. Risiko operasional tidak diikutsertakan dalam penelitian ini karena risiko tersebut hanya dapat dinilai secara akurat oleh perbankan sendiri karena menyangkut kondisi internal perbankan.

Penelitian terdahulu menelaah risiko bank syariah antara lain dilakukan oleh Prabowo (2009) yang menganalisis risiko dan imbal hasil pada Bank Syariah Mandiri pada tahun 2004-2006, dengan mengaplikasikan Metode Value at Risk (VaR) dan Risk Adjusted Return on Capital (RAROC). Sarker (1998) di Bangladesh meneliti kinerja, problem 
dan prospek perbankan syariah periode 1988-1997. Misman dan Bhatti (2010) meneliti level risiko yang dihadapi Bank Islam Malaysia Berhad pada tahun 2007 2009 yang digunakan untuk memprediksi imbal hasil pada tahun 2010. Abedifar et al. (2011) meneliti risiko kredit dan stabilitas 456 bank Islam di 22 negara periode 2001-2008. Grassa (2009) meneliti struktur penghasilan dan risiko pada bank syariah di negara-negara yang tergabung dalam Gulf Cooperation Councils pada tahun 2002-2008.

Penelitian ini berhasil mengonfirmasi bahwa jumlah rapat dewan direksi dan jumlah rapat komite pemantau risiko berpengaruh negatif terhadap risiko bank syariah. Hal ini berarti semakin intens dewan direksi dan komite pemantau risiko mengadakan pertemuan, semakin kecil risiko pembiayaan yang dihadapi oleh bank umum syariah. Sementara itu organ bank syariah lainnya, yakni dewan komisaris dan dewan pengawas syariah tidak memengaruhi risiko bank syariah.

Temuan penelitian ini mengimplikasikan perlunya upaya yang sungguh-sungguh dari pihak bank syariah, Dewan Syariah Nasional maupun pihak Bank Indonesia yang berwenang mengawasi perbankan syariah di Indonesia. Kepercayaan para pemangku kepentingan merupakan modal utama bisnis perbankan syariah. Oleh karena itu pembenahan internal dalam hal tata kelola bank syariah merupakan hal mendesak. Perbankan syariah di Indonesia masih relatif muda usianya. Dengan demikian pembenahan perlu digalakkan sejak dini agar proses operasionalisasi perbankan sesuai dengan prinsip kehati-hatian dan prinsip syariah.

\section{KERANGKA TEORITIS DAN PENGEMBANGAN HIPOTESIS}

\section{Stewardship Theory}

Teori keabdian (stewardship theory) adalah teori yang memandang bahwa para pemegang peran di dalam organisasi memiliki tanggung jawab atas amanah yang diembannya. Teori ini memiliki perbedaan dengan teori keagenan dalam memandang "model of man." Menurut teori ini pemegang peran organisasi termotivasi oleh kebutuhan berprestasi, mencapai kepuasan intrinsik melalui terpenuhinya tugas dan tanggung jawab pekerjaan, dan karenanya mendapatkan pengakuan dari sejawatnya (Donaldson dan Davis 1991). 
Analisis bank berbasis risiko

\section{Analisis Perbankan Berbasis Risiko}

Pada dasarnya bank syariah memiliki karakteristik yang berbeda dari bank konvensional, antara lain dalam hal instrumen keuangan maupun struktur laporan keuangannya. Namun demikian seperti halnya bank konvensional, bank syariah tetap tunduk pada rerangka yang sama dalam menganalisis risiko yang dihadapinya. Prinsip dan prosedur untuk mengukur dan mengendalian risiko sama dengan perbankan konvensional sehingga kerangka analisis untuk menilai risiko juga harus sama (Greuning dan Iqbal 2011).

Analisis perbankan tradisional didasarkan pada berbagai alat pengawasan kuantitatif untuk menilai kondisi suatu bank. Dalam hal ini biasanya digunakan rasio-rasio keuangan misalnya rasio yang berhubungan dengan likuiditas, kecukupan modal, kualitas dari portofolio investasi, tingkat pinjaman hubungan istimewa dan posisi valuta asing. Meskipun pengukuran ini sangat bermanfaat, tetapi pengukuran ini saja tidak cukup mengindikasikan profil risiko sebuah bank, stabilitas kondisi keuangan bank, ataupun prospek bank tersebut. termasuk faktor kualitatif penting dan menempatkan rasio-rasio keuangan dalam sebuah kerangka luas dari penilaian risiko dan manajemen risiko serta perubahan atau tren risikonya. Hal ini menempatkan aspek kelembagaan menjadi hal yang penting, seperti kualitas dan gaya tata kelola perusahan dan manajemen; kecukupan, kelengkapan serta konsistensi terhadap kebijakan dan prosedur bank; efektivitas dan kelengkapan pengendalian internal; serta ketepatan waktu, keakurasian sistem informasi manajemen dan dukungan informasi.

Iqbal dan Mirakhor (2007) memberikan gambaran profil risiko institusi keuangan islami (Islamic Financial Institution, IFI) dalam empat kelompok besar, yaitu risiko finansial, risiko bisnis, risiko treasury dan risiko tata kelola. Risiko tersebut juga terdapat dalam lembaga keuangan konvensional. Namun ada risiko spesifik bagi bank syariah dan lembaga keuangan lainnya yang muncul dari sifat yang berebeda dari intermediasi, produk dan format posisi keuangan dalam neraca.

Risiko dalam sistem profit-share (bagi hasil) berbentuk antara lain tidak terdapat suatu fixed and certain return 
sebagaimana bunga, tetapi dilakukan loss and profit sharing berdasarkan produktifitas nyata dari dana tersebut. Meskipun nisbah bagi hasil disepakati pada saat perikatan (akad) awal, tetapi perolehan riil dari bagi hasil ini baru diketahui setelah modal yang disetorkan para pihak benar-benar menghasilkan keuntungan. Jadi, hal yang bersifat pasti dari sistem ini adalah nisbah bagi hasilnya, bukan nilai riil bagi hasilnya. Terdapat kemungkinan fluktuasi dalam bagi hasil yang nyata, tergantung pada produktifitas nyata dari pemanfaatan dana.

\section{Prinsip-Prinsip Sistem Keuangan Syariah}

Istilah "sistem keuangan syariah" merupakan istilah yang relatif baru muncul kembali pada pertengahan tahun 1980. Referensi awal untuk kegiatan komersial atau dagang yang sesuai dengan prinsip-prinsip Islam disebut sebagai "bebas bunga." Namun menafsirkan sistem keuangan syariah hanya sebagai bebas dari bunga tidak mencerminkan keseluruhan sistemnya. Tidak dapat dibantah bahwa larangan menerima dan membayar bunga adalah inti dari ajaran Islam, tetapi hal tersebut didukung oleh prinsip-prinsip lain dari ajaran Islam yang menganjurkan keadilan sosial, berbagi risikohak dan kewajiban individual dan masyarakat, hak milik, dan kemurnian kontrak.

Greuning dan Iqbal (2011) merangkum karakteristik sistem perekonomian Islam sebagai berikut: (1) Prioritas utama dari ajaran Islam mengenai perekonomian adalah keadilan dan kesetaraaan dari produksi hingga distribusi; (2) Paradigma Islam menggabungkan spiritual dan kerangka moral yang menempatkan hubungan manusia di atas kepemilikan harta benda; (3) Sistem syariah menciptakan hubungan seimbang antara individu dan masyarakat; (4) Pengakuan dan perlindungan hak milik semua anggota masyarakat merupakan dasar dari suatu masyarakat yang berorientasi pada pemangku kepentingan, menjaga hak dan mengingatkan tanggung jawab mereka.

\section{Tata Kelola Perbankan Syariah}

Seiring dengan perkembangan industri perbankan syariah, maka tata kelola perusahaan yang baik atau Good Corporate Governance (GCG) pada industri perbankan syariah menjadi semakin penting untuk dilaksanakan. Keberadaan tata kelola bahkan 
berimplikasi luas dan kritikal terhadap perkembangan ekonomi dan kesejahteraan sosial (Lukviarman 2016). Tata kelola perusahaan mempertimbangkan keseimbangan antara tujuan ekonomi dan sosial dan keseimbangan antara tujuan individual dan masyarakat. Rerangka tata kelola adalah untuk meningkatkan penggunaan sumber daya secara efisien. Hal ini membutuhkan akuntabilitas pengelolaan sumber daya tersebut. Pada akhirnya tujuan tata kelola perusahaan adalah mencapai keselarasan kepentingan individual, korporasi, dan masyarakat.

GCG sangat diperlukan untuk membangun kepercayaan masyarakat karena pada dasarnya GCG didesain untuk melindungi kepentingan semua pihak yang berkepentingan (stakeholders). Untuk itu, menurut Pedoman GCG Perbankan Indonesia (2004) ada lima prinsip utama yang perlu diterapkan dalam tata kelola perusahaan, yakni keterbukaan, akuntabilitas, tanggung jawab, independensi, dan kewajaran. Dalam ketentuan syariah prinsip-prinsip ini diatur dalam al-qur'an dan hadits. Qur'an surat (QS) An-Nisa: 58 mengatur keterbukaan; akuntabilitas dalam QS AlFathir: 28, Az-Zumar: 9, Al-Mujadilah:
11; prinsip tanggung jawab dalam QS Al-Mudatstsir: 38. Independensi atau profesionalitas diatur dalam hadits riwayat (HR) Albany, HR Abu Daud. Kewajaran dan kesetaraan (fairness) diatur dalam QS An-Nahl: 90,

Untuk menciptakan industri perbankan syariah yang sehat dan tangguh, Bank Indonesia menerbitkan Peraturan Bank Indonesia Nomor 11/33/PBI/2009 tentang Pelaksanaan Good Corporate Governance Bagi Bank Umum Syariah dan Unit Usaha Syariah. Bank Umum Syariah yang selanjutnya disebut BUS adalah Bank Syariah yang dalam kegiatannya memberikan jasa dalam lalu lintas pembayaran. Pelaksanaan GCG merupakan hal yang wajib dilakukan oleh BUS dalam setiap kegiatan usaha di setiap jenjang organisasi.

Pelaksanaan tata kelola yang baik pada perbankan syariah setidak-tidaknya diwujudkan dalam: a. pelaksanaan tugas dan tanggung jawab Dewan Komisaris dan Direksi; b. kelengkapan dan pelaksanaan tugas komite-komite dan fungsi yang menjalankan pengendalian intern BUS; c. pelaksanaan tugas dan tanggung jawab Dewan Pengawas Syariah; d. penerapan fungsi kepatuhan, audit intern dan audit ekstern; e. batas 
maksimum penyaluran dana; dan $\mathrm{f}$. transparansi kondisi keuangan dan non keuangan BUS (PBI No. 11/33/PBI/2009). Pelaksanaan GCG merupakan salah satu upaya untuk melindungi kepentingan stakeholders dan meningkatkan kepatuhan terhadap peraturan perundang-undangan yang berlaku serta nilai-nilai etika yang berlaku secara umum pada industri perbankan syariah.

\section{Perumusan Hipotesis}

Dalam rangka menerapkan prinsip dasar Good Corporate Governance, bank wajib berpedoman pada berbagai ketentuan dan persyaratan yang terkait dengan pelaksanaan GCG. Selain itu dalam pelaksanaan GCG, industri perbankan syariah juga harus memenuhi prinsip syariah (sharia compliance). Penjelasan atas Peraturan Bank Indonesia Nomor 11/33/PBI/2009 tentang Pelaksanaan Good Corporate Governance Bagi Bank Umum Syariah dan Unit Usaha Syariah, menyatakan bahwa ketidaksesuaian tata kelola bank dengan prinsip syariah akan berpotensi menimbulkan berbagai risiko bagi industri perbankan syariah. Peraturan Bank Indonesia Nomor 13/23/PBI/2011 juga menyatakan dalam Pasal 3 bahwa pengawasan aktif dari Dewan Komisaris, Direksi, dan Dewan Pengawas Syariah merupakan salah satu unsur penerapan manajemen risiko perbankan syariah.

Risiko adalah ketidakpastian outcome atau peristiwa, terutama berkenaan dengan masa depan. Sedangkan risiko bisnis adalah besarnya variabilitas return perusahaan dan dapat menyebabkan kebangkrutan (Miller dan Bromiley 1990). Risiko yang paling besar dihadapi perbankan adalah risiko kredit/pembiayaan, karena transaksi pembiayaan merupakan operasi utama entitas. Oleh karena itu tata kelola perbankan ditujukan antara lain terutama untuk menekan risiko kerugian karena klien yang gagal memenuhi kewajiban pembiayaan.

$$
\text { Dewan Komisaris wajib }
$$
melakukan pengawasan atas terselenggaranya pelaksanaan GCG dalam setiap kegiatan usaha BUS pada seluruh tingkatan atau jenjang organisasi. Tanggung jawab utamanya adalah memilih CEO yang kompeten dan etis, memonitor tujuan operasional, finansial, dan strategi keberlanjutan yang dilakukan manajemen (Rezaee 2007). Selain pengawasan, dewan komisaris memiliki peran esensial dalam hal fungsi pemberian nasihat (advisory function). 
Rezaee (2007) menyatakan terdapat beberapa atribut yang memengaruhi kualitas fungsi pengawasan yang dilakukan oleh dewan komisaris. Salah satunya adalah independensi dewan.

Independensi dewan komisaris merupakan suatu aspek tata kelola penting yang berdampak pada efektivitas fungsinya (Rezaee 2007). Komisaris independen adalah komisaris yang tidak berasal dari pihak terafiliasi atau memiliki hubungan bisnis dan kekeluargaan dengan pemegang saham pengendali, anggota direksi dan dewan komisaris lain, serta dengan perusahaan itu sendiri (KNKG 2006). Proporsi komisaris independen menjadi masalah penting karena pedoman GCG Indonesia menentukan bahwa jumlah komisaris independen harus dapat menjamin agar mekanisme pengawasan berjalan secara efektif. Diduga semakin besar proporsi komisaris independen fungsi pengawasan akan semakin ketat dan pemberian nasihat semakin intens. Banyaknya sumbangsaran dan pengawasan yang dilakukan oleh dewan komisaris juga diduga tercermin dari banyaknya pertemuan internal dewan komisaris maupun pertemuan dewan komisaris dengan dewan direksi.
Berdasar penjelasan ini dirumuskan hipotesis:

H1. Proporsi komisaris independen berpengaruh negatif pada risiko bank syariah

H2. Jumlah rapat dewan komisaris berpengaruh negatif pada risiko bank syariah

Dalam melaksanakan tugasnya, dewan komisaris dapat membentuk komite. Komite yang minimal harus dibentuk menurut pedoman GCG Indonesia adalah komite audit. Pembentukan komite lain disesuaikan dengan kebutuhan (KNKG 2006). Komite Audit merupakan organ penting yang memastikan terlaksananya prinsip check and balances. Komite ini bertugas sebagai fasilitator bagi Dewan Komisaris untuk memastikan, antara lain, laporan keuangan disajikan secara wajar dan struktur pengendalian internal bank telah cukup untuk menjaga agar manajemen menjalankan praktik perbankan yang sehat sesuai dengan prinsip kehatihatian. Komite lain yang dapat dibentuk oleh dewan komisaris adalah komite pemantau risiko. Semakin efektif kedua komite menjalankan fungsinya diduga dapat menekan besarnya risiko pembiayaan bank. 
H3. Jumlah anggota komite audit berpengaruh negatif pada risiko bank syariah.

H4. Jumlah rapat komite audit berpengaruh negatif pada risiko bank syariah.

H5. Jumlah anggota komite pemantau risiko berpengaruh negatif pada risiko bank syariah.

H6. Jumlah rapat komite pemantau risiko berpengaruh negatif pada risiko bank syariah.

Dewan direksi bertanggung jawab atas seluruh fungsi manajerial, yang meliputi pengembangan dan eksekusi strategi korporasi, pengamanan sumber daya, penilaian kinerja finansial, penyajian laporan keuangan yang wajar, dan peningkatan nilai jangka panjang (Rezaee 2007). Dengan demikian salah satu area tanggung jawab direksi bank syariah adalah operasi bank. Ketika dewan direksi makin terlibat dalam operasional mikro maka risiko bank akan dapat ditekan.

H7. Jumlah anggota dewan direksi berpengaruh negatif pada risiko bank syariah.

H8. Jumlah rapat dewan direksi berpengaruh negatif pada risiko bank syariah.
Dewan Pengawas Syariah adalah badan independen yang bertugas melakukan pengarahan (directing), pemberian konsultasi (consulting), melakukan evaluasi (evaluating), dan pengawasan (supervising) kegiatan bank syariah dalam rangka memastikan bahwa kegiatan usaha bank syariah terebut mematuhi prinsip syariah sebagaimana ditentukan oleh fatwa dan syariah Islam. Tugas ini dilakukan minimal sekali dalam sebulan. Jumlah dan kehadiran anggota DPS di dalam rapat diduga berpengaruh negatif pada risiko yang ditanggung oleh bank.

H9. Jumlah anggota dewan pengawas syariah berpengaruh pada risiko bank syariah.

H10. Jumlah rapat dewan pengawas syariah berpengaruh pada risiko bank syariah.

\section{METODE PENELITIAN}

Populasi penelitian ini adalah perbankan syariah di Indonesia yang ada pada tahun 2008-2016. Data yang secara lengkap dapat diperoleh berjumlah 40 . Meski mencakup perioda yang cukup lama, namun keberadaan beberapa bank syariah di Indonesai, baik yang berbentuk BUS maupun UUS, masih 
belum banyak dan masih berusia relatif muda.

Variabel independen penelitian ini mencakup organ-organ yang wajib ada di perbankan syariah. Dengan demikian akan diuji variabel-variabel yang diasumsikan merupakan proksi keefektifan organ-organ ini, yakni meliputi proporsi komisaris independen dan jumlah pertemuan dewan komisaris, jumlah anggota dan rapat komite audit, komite pemantau risiko, dewan direksi, dan dewan pengawas syariah. Variabel dependen penelitian ini adalah risiko pembiayaan bank syariah. Risiko pembiayaan adalah risiko akibat kegagalan nasabah atau pihak lain dalam memenuhi kewajiban kepada bank sesuai dengan akad yang disepakati. Risiko ini diukur dengan Non Performing Financing (NPF).

Pengolahan data dilakukan dengan uji regresi. Uji ini dilakukan setelah dilakukan uji asumsi klasik. Persamaan regresi adalah sebagai berikut:

$$
\begin{aligned}
\mathrm{Y}= & \beta 0+\beta 1 \mathrm{PKI}+\beta 2 \mathrm{JRDK}+\beta 3 \mathrm{JD}+\beta 4 \mathrm{JRD}+\beta 5 \mathrm{JKPR}+\beta 6 \mathrm{JRKPR}+ \\
& \beta 7 \mathrm{JKA}+\beta 8 \mathrm{JRKA}+\beta 9 \mathrm{JDPS}+\beta 10 \mathrm{JRDPS}+\varepsilon
\end{aligned}
$$

Dalam hal ini:

$\mathrm{Y} \quad=$ Risiko pembiayaan

$\beta 0=$ Konstanta

$\beta 1-\beta 10=$ Koefisien

PK I = Proporsi komisaris independen

JRDK = Jumlah rapat dewan komisaris

JD = Jumlah direksi

JRD = Jumlah rapat direksi
JDPS = Jumlah dewan pengawas syariah

JRDR = Jumlah rapat dewan pengawas syariah

JKA =Jumlah komite audit

JRKA =Jumlah rapat komite audit

JKPR =Jumlah komite pemantau risiko

JRKPR=Jumlah rapat komite pemantau risiko

\section{HASIL PENELITIAN DAN PEMBAHASAN}

\section{Statistik Deskriptif}

Statistik deskriptif variabel penelitian ditunjukkan pada tabel 1 berikut ini. 
Tabel 1

Statistik Deskriptif

\begin{tabular}{lrrrrr}
\hline \multicolumn{1}{c}{$\begin{array}{c}\text { Statistik } \\
\text { Deskriptif }\end{array}$} & $\boldsymbol{N}$ & Minimum & Maximum & Mean & Std. Deviation \\
\hline Proporsi KI & 40 & 40 & 1,00 &, 6275 &, 12210 \\
Rapat Dekom & 40 & 8 & 58 & 23,03 & 11,457 \\
Jumlah Komdit & 40 & 3 & 7 & 3,80 & 1,114 \\
Rapat Komdit & 40 & 3 & 58 & 14,32 & 11,454 \\
Jumlah Direksi & 40 & 3 & 7 & 4,40 & 1,150 \\
Rapat Direksi & 40 & 24 & 112 & 49,72 & 18,109 \\
Jumlah DPS & 40 & 2 & 4 & 2,50 &, 599 \\
Rapat DPS & 40 & 5 & 25 & 14,87 & 3,797 \\
Jumlah KPR & 40 & 2 & 5 & 3,77 &, 920 \\
Rapat KPR & 40 & 2 & 59 & 14,25 & 11,650 \\
Risiko Bank & 40 &, 00 & 6,84 & 2,1088 & 1,58452 \\
Valid N (listwise) & 40 & & & & \\
\hline
\end{tabular}

Dari tabel 1 terdapat hal-hal penting yang perlu diulas. Diketahui bahwa di dalam dewan komisaris ratarata sebanyak $63 \%$ anggotanya adalah komisaris independen. Komisaris independen adalah anggota dewan komisaris yang tidak memiliki hubungan keuangan, kepengurusan, kepemilikan saham dan/atau hubungan keluarga dengan anggota dewan komisaris lainnya, direksi dan/atau pemegang saham pengendali atau hubungan dengan bank, yang dapat memengaruhi kemampuannya untuk bertindak independen. Beberapa bank syariah yang menjadi sampel penelitian menunjukkan ketidaksesuaian dengan Peraturan Bank Indonesia (PBI) nomor 11/3/PBI/2009 tentang Bank Umum Syariah, pasal 25 ayat (4) yang berbunyi "paling kurang 50\% (lima puluh persen) dari jumlah anggota Dewan Komisaris adalah Komisaris Independen." Hal ini ditunjukkan oleh data proporsi komisaris independen yakni minimal 40\%, sehingga diketahui ada bank syariah yang belum memenuhi ketentuan proporsi komisaris independen 50\% dalam dewan komisaris.

Dalam rangka mendukung efektivitas pelaksanaan tugas dan tanggung jawabnya, Dewan Komisaris wajib membentuk komite-komite, yang dua di antaranya diinvestigasi dalam penelitian ini, yakni komite audit dan komite pemantau risiko. Yang juga perlu digarisbawahi dari hasil statistik deskriptif di atas adalah beberapa bank syariah masih memiliki jumlah anggota komite pemantau risiko kurang dari 3 
orang (yakni 2 orang). Pasal 34 dalam PBI 11/3/PBI/2009 tentang pelaksanaan Good Corporate Governance Bagi Bank Umum Syariah dan Unit Usaha Syariah menentukan secara tersirat bahwa minimal jumlah anggota komite pemantau risiko adalah 3 orang. Pasal itu menyatakan bahwa anggota komite ini paling kurang terdiri dari seorang komisaris independen, seorang pihak independen yang memiliki keahlian di bidang perbankan syariah, dan seorang pihak independen yang memiliki keahlian di bidang manajemen risiko.

PBI 11/33/PBI/2009 tentang pelaksanaan Good Corporate Governance Bagi Bank Umum Syariah dan Unit Usaha Syariah pasal 48 menyatakan bahwa rapat DPS wajib diselenggarakan paling kurang satu kali dalam satu bulan. Berdasar tabel 1 diketahui bahwa rata-rata DPS bank syariah telah memenuhi ketentuan tersebut (14 kali), namun terdapat DPS di bank syariah belum memenuhi ketentuan tersebut karena nilai minimal rapat DPS (yakni 5) masih di bawah ketentuan pasal tersebut yakni sebanyak 12 kali.

\section{Hasil Pengujian Hipotesis}

Sebelum dilakukan pengujian regresi terlebih dahulu dilakukan pengujian asumsi klasik untuk mengetahui bahwa persamaan regresi memenuhi persyaratan sebagai persamaan yang baik. Hasil pengujian multikolinearitas atas persamaan regresi ditunjukkan pada tabel 2.

Tabel 2

Hasil Pengujian Multikolinearitas

\begin{tabular}{llcc}
\hline \multicolumn{3}{c}{ Model } & \multicolumn{2}{c}{ Coefficients $^{\boldsymbol{a}}$} \\
\cline { 3 - 4 } & Collinearity Statistics \\
\hline 1 & (Constant) & & \\
& Proporsi KI &, 663 & 1,508 \\
Rapat Dekom &, 437 & 2,289 \\
Jumlah KPR &, 329 & 3,038 \\
Rapat KPR &, 247 & 4,047 \\
Jumlah Komdit &, 421 & 2,373 \\
Rapat Komdit &, 309 & 3,240 \\
Jumlah Direksi &, 209 & 4,786 \\
Rapat Direksi &, 764 & 1,309 \\
& Jumlah DPS &, 270 & 3,699 \\
Rapat DPS &, 537 & 1,863 \\
\hline
\end{tabular}

a. Dependent Variable: Risiko Bank 
Berdasarkan tabel 2 diketahui bahwa tidak ada nilai tolerance di bawah 0,10 ; namun berkisar antara 0,209-0,764. Demikian pula tidak berada nilai VIF yang berada di atas 10 , namun berkisar antara 1,309-4,786. Dengan demikian tidak ada korelasi yang tinggi atau sempurna antar variabel independen penelitian ini, atau dengan kata lain tidak terjadi multikolinearitas.

Hasil pengujian asumsi klasik heteroskedastisitas ditunjukkan pada tabel 3. Pengujian dilakukan dengan uji Park.

Tabel

Hasil Pengujian Heteroskedastisitas

\begin{tabular}{|c|c|c|c|c|c|c|}
\hline \multicolumn{7}{|c|}{ Coefficients $^{a}$} \\
\hline & \multirow{2}{*}{ Model } & \multicolumn{2}{|c|}{$\begin{array}{c}\text { Unstandardized } \\
\text { Coefficients }\end{array}$} & \multirow{2}{*}{$\begin{array}{c}\begin{array}{c}\text { Standardized } \\
\text { Coefficients }\end{array} \\
\text { Beta }\end{array}$} & \multirow{2}{*}{$t$} & \multirow{2}{*}{ Sig. } \\
\hline & & $\boldsymbol{B}$ & $\begin{array}{c}\text { Std. } \\
\text { Error }\end{array}$ & & & \\
\hline \multirow[t]{11}{*}{1} & (Constant) & ,760 & 2,960 & & ,257 & ,799 \\
\hline & LnPropKI &,- 848 & 1,101 &,- 152 &,- 771 & ,447 \\
\hline & LnRptDekom &, 323 &, 622 &, 159 & ,519 & 608 \\
\hline & LnJmlKA &,- 620 & ,987 &,- 156 &,- 629 &, 535 \\
\hline & LnRptKA & ,666 & ,624 & ,474 & 1,068 & ,294 \\
\hline & LnJmlDir & ,631 & 1,383 &, 162 & ,456 & ,652 \\
\hline & LnRptDir &,- 487 & 661 &,- 159 &,- 737 & ,467 \\
\hline & LnJDPS &,- 330 & 1,270 &,- 073 &,- 260 & ,797 \\
\hline & LnRptDPS &, 120 &, 777 & ,034 &, 155 & ,878 \\
\hline & LnJKPR & ,427 & 1,389 & , 101 & ,307 & ,761 \\
\hline & LnRptKPR &,- 607 & ,618 &,- 431 &,- 982 & ,334 \\
\hline
\end{tabular}

a. Dependent Variable: Kuadrat Residual

Hasil SPSS menunjukkan dilakukan dengan uji Durbin Watson. koefisien seluruh parameter tidak Pengujian ini bertujuan untuk signifikan pada 0,01 . Hal ini berarti tidak ada heteroskedastisitas atau dengan kata lain terdapat homoskedastisitas. Nilai residual model regresi penelitian ini memiliki variance yang sama.

Pengujian asumsi klasik dalam tabel 4.

berikutnya adalah uji autokorelasi yang mengetahui apakah dalam model regresi terdapat korelasi antarkesalahan pengganggu (residual) pada periode $\mathrm{t}$ dengan kesalahan pada periode sebelumnya. Hasil pengujian ditunjukkan 
Tabel 4

Hasil Pengujian Autokorelasi

\begin{tabular}{llrrrrr}
\hline \multicolumn{7}{c}{ Model Summary } \\
\hline Model & \multirow{2}{*}{ R Square } & $\begin{array}{c}\text { Adjusted } \boldsymbol{R} \\
\text { Square }\end{array}$ & $\begin{array}{l}\text { Std. Error of } \\
\text { the Estimate }\end{array}$ & $\begin{array}{l}\text { Durbin- } \\
\text { Watson }\end{array}$ \\
\hline 1 &, $741^{\mathrm{a}}$ &, 549 &, 393 & 1,23438 & 1,788 \\
\hline
\end{tabular}

a. Predictors: (Constant), Rapat KPR, Proporsi KI, Rapat DPS, Jumlah Direksi, Rapat Direksi, Rapat Dekom, Jumlah Komdit, Jumlah KPR, Rapat Komdit, Jumlah DPS

b. Dependent Variable: Risiko Bank

Jika nilai Durbin-Watson di atas $(1,787)$ dibandingkan dengan nilai tabel dengan menggunakan nilai signifikansi 5\%, jumlah sampel 40 dan jumlah variabel independen 10, maka pada tabel Durbin Watson didapatkan nilai batas atas (du) 2.149 dan batas bawah (dl) 0.952. Oleh karena nilai Durbin Watson berada di antara batas bawah dan batas atas, maka dapat disimpulkan tidak ada autokorelasi positif.

Pengujian asumsi klasik berikutnya, yakni pengujian normalitas, dilakukan dengan uji KolmogorovSmirnov. Besarnya nilai Kolmogorov-
Smirnov adalah 0,132 dengan signifikansi 0,75 . Dengan demikian disimpulkan bahwa residual terdistribusi secara normal.

Pengujian regresi berganda dengan SPSS menunjukkan hasil-hasil berikut ini. Untuk mengukur goodness of fit model regresi dilakukan uji F. Hasil pengujian yang ditunjukkan pada tabel 5 menunjukkan nilai $F$ sebesar 3,526 dengan probabilitas 0,004. Angka probabilitas ini jauh lebih kecil dari pada 0,05. Dengan demikian dapat disimpulkan model regresi adalah fit untuk diujikan.

Tabel 5

Hasil Pengujian Signifikansi Simultan (Uji Statistik F)

ANOVA ${ }^{a}$

\begin{tabular}{|c|c|c|c|c|c|c|}
\hline & Model & Sum of Squares & $d f$ & $\begin{array}{l}\text { Mean } \\
\text { Square }\end{array}$ & $\boldsymbol{F}$ & Sig. \\
\hline \multirow{3}{*}{1} & Regression & 53,730 & 10 & 5,373 & 3,526 &, $004^{b}$ \\
\hline & Residual & 44,187 & 29 & 1,524 & & \\
\hline & Total & 97,917 & 39 & & & \\
\hline
\end{tabular}

a. Dependent Variable: Risiko Bank

b. Predictors: (Constant), Rapat KPR, Proporsi KI, Rapat DPS, Jumlah Direksi, Rapat

Direksi, Rapat Dekom, Jumlah Komdit, Jumlah KPR, Rapat Komdit, Jumlah DPS 
Hasil pengujian parameter individual ditampilkan pada tabel 6 berikut.

Tabel 6

Hasil Pengujian Parameter Individual (Uji Statistik t)

\begin{tabular}{|c|c|c|c|c|c|c|}
\hline \multicolumn{7}{|c|}{ Coefficients $^{a}$} \\
\hline & \multirow[t]{2}{*}{ Model } & \multicolumn{2}{|c|}{$\begin{array}{c}\text { Unstandardized } \\
\text { Coefficients }\end{array}$} & \multirow{2}{*}{$\begin{array}{c}\begin{array}{c}\text { Standardized } \\
\text { Coefficients }\end{array} \\
\text { Beta } \\
\end{array}$} & \multirow[t]{2}{*}{$T$} & \multirow[t]{2}{*}{ Sig. } \\
\hline & & $\boldsymbol{B}$ & Std. Error & & & \\
\hline \multirow[t]{11}{*}{1} & (Constant) &,- 316 & 2,234 & &,- 142 & ,888 \\
\hline & Proporsi KI & $-2,217$ & 1,988 &,- 171 & $-1,115$ & ,274 \\
\hline & Rapat Dekom & ,022 & ,026 &, 157 & ,834 & ,411 \\
\hline & Jumlah Komdit & ,964 & ,273 & ,678 & 3,526 &, 001 \\
\hline & Rapat Komdit & ,027 & 031 & 196 &, 871 & ,391 \\
\hline & Jumlah KPR &,- 258 & ,375 &,- 150 &,- 690 & ,496 \\
\hline & Rapat KPR &,- 059 & ,034 &,- 431 & $-1,716$ & ,097 \\
\hline & Jumlah Direksi &,- 149 & ,376 &,- 108 &,- 395 & ,695 \\
\hline & Rapat Direksi &,- 031 & ,012 &,- 349 & $-2,445$ &, 021 \\
\hline & Jumlah DPS & 1,358 & ,635 &, 514 & 2,141 &, 041 \\
\hline & Rapat DPS &,- 010 &, 071 &,- 024 &,- 142 & ,888 \\
\hline
\end{tabular}

Dependent Variable: Risiko Bank

Hasil pengujian $\mathrm{t}$ statistik signifikansi 0,10. Namun merujuk pada menunjukkan bahwa variabel independen hipotesis yang diajukan, hanya rapat jumlah komite audit, rapat direksi dan KPR dan rapat dewan direksilah yang jumlah Dewan Pengawas Syariah berpengaruh terhadap risiko bank syariah dengan nilai signifikansi 0,05 ; sedangkan rapat KPR berpengaruh signifikan pada berpengaruh negatif pada risiko bank syariah. Dengan demikian dua hipotesis inilah yang tidak dapat ditolak (yakni hipotesis 6 dan hipotesis 8).

risiko bank syariah dengan nilai

Hasil pengujian koefisien determinasi ditunjukkan pada tabel 7.

Tabel 7

\section{Hasil Pengujian Koefisien Determinasi}

\begin{tabular}{ccccc}
\hline \multicolumn{4}{c}{ Model Summary } \\
\hline Model & $\boldsymbol{R}$ & $\boldsymbol{R}$ Square & Adjusted $\boldsymbol{R}$ Square & Std. Error of the Estimate \\
\hline 1 &, $741^{\mathrm{a}}$ &, 549 &, 393 & 1,23438 \\
\hline
\end{tabular}

a. Predictors: (Constant), Rapat KPR, Proporsi KI, Rapat DPS, Jumlah Direksi, Rapat

Direksi, Rapat Dekom, Jumlah Komdit, Jumlah KPR, Rapat Komdit, Jumlah DPS

Berdasar tabel di atas diketahui ini berarti 39,3\% variasi risiko bank besarnya adjusted $\mathrm{R}^{2}$ adalah 0,393 . Hal syariah dapat dijelaskan oleh variabel 
independen penelitian ini, sedangkan sisanya $60,7 \%$ dijelaskan oleh sebabsebab lain di luar model.

\section{Pembahasan}

Penelitian ini menguji pengaruh tata kelola bank syariah terhadap risiko bank syariah periode 2008-2016. Tata kelola bank syariah yang diteliti meliputi efektivitas dewan komisaris, komite pemantau risiko, komite audit, direksi, dan dewan pengawas syariah. Efektivitas organ ini dilihat dari sudut jumlah anggota organ tersebut dan jumlah rapat yang diselenggarakan oleh organ tersebut. Khusus untuk dewan komisaris, proporsi komisaris independen merupakan variabel independen yang diteliti. Pemilihan organ ini didasarkan pada ketentuan Bank Indonesia yang mewajibkan dibentuknya organ-organ ini untuk mendukung terciptanya tata kelola yang baik di bank umum syariah maupun unit usaha syariah.

Risiko bank syariah yang difokuskan dalam penelitian ini adalah risiko pembiayaan. Risiko pembiayaan adalah risiko kerugian yang dikaitkan dengan kemungkinan kegagalan nasabah membayar kewajibannya melunasi pembiayaan yang disalurkan. Risiko pembiayaan merupakan salah satu risiko yang dihadapi perbankan syariah menurut Peraturan Bank Indonesia Nomor 13/23/PBI/2011 tentang Penerapan Manajemen Risiko Bagi Bank Umum Syariah dan Unit Usaha Syariah. Risiko pembiayaan bank syariah adalah risiko yang dominan dihadapi bank syariah karena core business-nya. Oleh karenanya upaya tata kelola bank syariah difokuskan, salah satunya, untuk menekan risiko tersebut.

Perbankan syariah dituntut mampu mengelola risiko yang dihadapi berdasarkan dua ketentuan sekaligus yaitu ketentuan syariah maupun ketentuan perbankan. Karena kondisi bank syariah yang beragam, maka penerapan manajemen risiko pada perbankan syariah disesuaikan dengan ukuran dan kompleksitas usaha serta kemampuan bank. Tata kelola bank diindikasikan sebagai salah satu hal yang berperan penting dalam menentukan tingkat risiko yang dihadapi oleh bank.

Dari Pasal 3 Peraturan Bank Indonesia Nomor 13/23/PBI/2011 dapat diketahui bahwa pengawasan aktif dari Dewan Komisaris, Direksi, dan Dewan Pengawas Syariah merupakan salah satu unsur penerapan manajemen risiko perbankan syariah. Komponen lain menurut ketentuan tersebut adalah 
kecukupan kebijakan, prosedur, dan penetapan limit manajemen risiko; kecukupan proses identifikasi, pengukuran, pemantauan, dan pengendalian risiko serta sistem informasi manajemen risiko; dan sistem pengendalian intern yang menyeluruh. Berdasarkan ketentuan Bank Indonesia ini diketahui pula besarnya peran komite pemantau risiko.

Penelitian ini berhasil mengonfirmasi bahwa jumlah rapat dewan direksi dan jumlah rapat komite pemantau risiko berpengaruh negatif terhadap risiko bank syariah. Hal ini berarti semakin intens dewan direksi dan komite pemantau risiko mengadakan pertemuan, semakin kecil risiko pembiayaan yang dihadapi oleh bank umum syariah. Sementara itu organ bank syariah lainnya, yakni dewan komisaris dan dewan pengawas syariah tidak memengaruhi risiko bank syariah.

Direksi bank syariah memiliki kewajiban melaksanakan tata kelola yang baik dalam setiap kegiatan BUS dan UUS pada seluruh tingkatan atau jenjang organisasi. Fungsi direksi paling tidak meliputi audit intern, manajemen risiko dan komite manajemen risiko, dan kepatuhan. Rapat direksi memiliki peran krusial karena pasal 31 dalam PBI
11/33/PBI/2009 tentang pelaksanaan Good Corporate Governance Bagi Bank Umum Syariah dan Unit Usaha Syariah menentukan bahwa setiap kebijakan dan keputusan strategis wajib diputuskan melalui rapat direksi. Dengan demikian hasil penelitian ini konsisten dengan ketentuan tersebut, semakin intens rapat dewan direksi dilakukan maka semakin rendah risiko pembiayaan bank syariah. Setiap ada permasalahan mendesak terkait risiko pembiayaan, dapat segera ditangani segenap jajaran bank syariah mengacu pada kebijakan dan keputusan yang dihasilkan dalam rapat dewan direksi.

Penelitian ini juga membuktikan bahwa risiko bank syariah dipengaruhi oleh jumlah rapat komite pemantau risiko yang merupakan proksi dari efektivitas komite pemantau risiko. Komite pemantau risiko merupakan salah satu komite yang dibentuk oleh dewan komisaris yang diketuai oleh komisaris independen. Komite Pemantau Risiko mempunyai tugas dan tanggung jawab meliputi melakukan evaluasi tentang kebijakan manajemen risiko, melakukan evaluasi tentang kesesuaian antara kebijakan manajemen risiko dengan pelaksanaan kebijakan tersebut, melakukan evaluasi pelaksanaan tugas 
Komite Manajemen Risiko dan Satuan Kerja Manajemen Risiko. Hasil pekerjaan komite ini berupa rekomendasi kepada Dewan Komisaris. Dengan jumlah rapat komite ini yang lebih banyak maka risiko pembiayaan bank syariah akan semakin kecil.

Penelitian ini tidak berhasil menunjukkan bukti pengaruh organ bank syariah lain terhadap risiko yang ditanggung bank syariah. Efektivitas dewan komisaris, yang dalam penelitian ini diproksikan dengan proporsi komisaris independen dan jumlah rapat dewan komisaris, tidak berpengaruh pada risiko pembiayaan bank syariah. Rezaee (2007) menyatakan bahwa dalam menjalankan fungsi pengawasan, dewan komisaris perlu berhati-hati agar tidak terlibat pada hal-hal detil (micromanage) dengan melibatkan dewan ini pada keputusan manajerial dan operasional. Mereka harus mengawasi strategi manjerial, namun mereka tidak bertanggung jawab pada implementasi strategi tersebut (Rezaee 2007: 88). Hal ini bisa jadi menjadi sebab tidak signifikannya pengaruh dewan komisaris dalam menekan risiko pembiayaan bank syariah.

Berdasar statistik deskriptif diketahui pula belum optimalnya kepatuhan bank syariah pada ketentuan terkait proporsi komisaris independen. Nilai minimal aktual proporsi komisaris independen adalah $40 \%$. Hal ini belum memenuhi ketentuan proporsi komisaris independen 50\% dalam dewan komisaris. Hal ini bisa jadi memengaruhi ketidaksignifikanan peran dewan komisaris dalam menekan risiko bank syariah.

Penelitian ini tidak menunjukkan dukungan atas hipotesis yang diajukan terkait keberadaan komite audit untuk menekan risiko pembiayaan bank syariah, bahkan jumlah komite audit justru berpengaruh positif pada risiko bank syariah. Komite audit memiliki tugas dan tanggung jawab meliputi, antara lain, melakukan evaluasi atas pelaksanaan audit intern dalam rangka menilai kecukupan pengendalian intern termasuk kecukupan proses pelaporan keuangan. Tugas dan tanggung jawab ini dapat dikatakan tidak secara langsung berkaitan dengan risiko pembiayaan bank syariah, berbeda dengan tugas komite pemantau risiko. Makin banyaknya jumlah komite audit bisa jadi justru malah berpengaruh buruk pada risiko pembiayaan ketika komite ini melakukan tugas yang bukan kewajiban utamanya. 
Penelitian ini menunjukkan bukti tidak signifikannya dewan pengawas syariah pada risiko bank syariah. Jumlah DPS malah berpengaruh positif pada risiko pembiayaan bank syariah. Campur tangan DPS atas risiko pembiayaan bank syariah dilakukan tidak secara langsung. Temuan DPS atas praktik bank syariah disampaikan terlebih dahulu kepada direksi. Pasal 21 PBI 11/2009 menentukan bahwa temuan dan/atau rekomendasi dari hasil pengawasan Bank Indonesia, auditor internal, Dewan Pengawas Syariah dan/atau auditor ekstern ditindaklanjuti oleh Direksi. Statistik deskriptif juga menunjukkan terdapat DPS di bank syariah yang belum memenuhi ketentuan BI untuk melakukan rapat minimal sebanyak 12 kali dalam setahun (nilai minimal rapat DPS aktual yakni 5). Hal ini bisa jadi memengaruhi efektivitas peran dan fungsi DPS di bank syariah.

Penelitian ini membuktikan bahwa pelaksanaan tata kelola yang baik oleh bank syariah dapat memperkecil risiko bank syariah. Organ-organ yang terkait langsung dengan risiko pembiayaan bank syariah, yakni dewan direksi yang menangani operasional bank syariah sehari-hari dan komite pemantau risiko, berperan langsung menekan risiko ini. Dengan demikian penelitian ini mendukung Penjelasan atas Peraturan Bank Indonesia Nomor 11/33/PBI/2009 tentang Pelaksanaan Good Corporate Governance Bagi Bank Umum Syariah dan Unit Usaha Syariah yang menyatakan bahwa ketidaksesuaian tata kelola bank dengan prinsip syariah akan berpotensi menimbulkan berbagai risiko bagi industri perbankan syariah.

Hasil penelitian ini relatif konsisten dengan hasil penelitian Grassa (2009) yang menemukan bank syariah yang memperluas produk bagi hasil (profit-loss-sharing) memiliki risiko yang lebih tinggi dan risiko ketidakmampuan membayar kredit yang lebih tinggi dibanding bank yang kurang berinvestasi dengan skema produk semacam itu. Tata kelola yang baik merupakan upaya untuk memitigasi risiko pembiayaan ini. Hasil penelitian ini sedikit banyak mendukung Peraturan Bank Indonesia Nomor 13/23/PBI/2011 Pasal 3 yang menyatakan bahwa pengawasan aktif dari Dewan Komisaris, Direksi, dan Dewan Pengawas Syariah merupakan salah satu unsur penerapan manajemen risiko perbankan syariah.

\section{KESIMPULAN DAN SARAN}

Penelitian ini bertujuan menguji pengaruh tata kelola bank syariah 
terhadap risiko bank syariah periode 2008-2016. Dengan merujuk pada berbagai ketentuan Bank Indonesia dan Komite Nasional Kebijakan Governance, maka organ-organ yang dijadikan fokus penelitian meliputi Dewan Komisaris (dan komite-komite yang dibentuknya, yakni komite pemantau risiko dan komite audit), dewan direksi, dan dewan pengawas syariah. Karena keberadaan organ-organ ini bersifat wajib di dalam bank syariah, maka penelitian ini menginvestigasi keefektivan organ-organ tersebut. Hal ini diproksikan dengan jumlah anggota dan jumlah pertemuan yang diselenggarakan. Khusus untuk dewan komisaris, proporsi komisaris independenlah yang diteliti. Hal ini terkait peran penting komisaris independen.

Hasil penelitian menunjukkan jumlah rapat dewan direksi dan jumlah rapat komite pemantau risiko berpengaruh negatif pada risiko bank syariah. Organ-organ ini terkait secara langsung dengan upaya menekan risiko pembiayaan bank syariah. Sementara itu dewan komisaris, komite audit, dan dewan pengawas syariah tidak berpengaruh negatif pada risiko pembiayaan bank syariah. Hal ini diduga karena tugas pokok dan fungsi masing- masing organ tersebut yang tidak terkait langsung dengan risiko pembiayaan bank syariah. Selain itu, statistik deskriptif menunjukkan kurang optimalnya kepatuhan bank syariah atas ketentuan Bank Indonesia untuk mewujudkan tata kelola yang baik, misalnya batas minimal jumlah komisaris independen dan batas minimal jumlah rapat yang diselenggarakan dewan pengawas syariah dalam setahun.

Penelitian ini mendukung ketentuan yang diatur oleh Bank Indonesia maupun Komite Nasional Kebijakan Governance, misalnya Peraturan Bank Indonesia Nomor 11/33/PBI/2009 tentang Pelaksanaan Good Corporate Governance Bagi Bank Umum Syariah dan Unit Usaha Syariah. Ketidaksesuaian tata kelola bank dengan prinsip kehati-hatian dan prinsip syariah menimbulkan berbagai risiko bagi industri perbankan syariah. Penelitian ini berimplikasi pada perlu pengawasan BI yang lebih ketat atas penerapan peraturan BI karena masih ditemui ketidaksesuaian aturan dengan praktik di lapangan. Hal ini dapat memengaruhi kepercayaan para pemangku kepentingan atas operasional dan kepatuhan bank syariah.

Penelitian ini tidak dapat melibatkan jumlah sampel yang besar 
meski periode yang diamati sudah cukup panjang, yakni 9 tahun. Jumlah bank syariah di Indonesia belum sebanyak bank konvensional dan bank syariah yang ada pun masih relatif belum lama berdiri. Penelitian ini lebih mengandalkan data bank syariah yang dipublikasi di internet dalam bentuk laporan manajemen atau laporan GCG dan laporan tahunan perusahaan. adalah minimnya data BUS yang dijadikan sampel. Untuk penelitian selanjutnya, perlu diupayakan mengisi data-data yang belum lengkap dengan mencari sumber data yang lain, misalnya dengan wawancara atau melihat secara langsung dokumen bank.

Berdasar hasil penelitian ini, perlu dilakukan upaya yang sungguh-sungguh dari pihak bank syariah, Dewan Syariah Nasional maupun pihak Bank Indonesia yang berwenang mengawasi perbankan syariah di Indonesia. Kepercayaan para pemangku kepentingan merupakan modal utama bisnis perbankan syariah. Oleh karena itu pembenahan internal dalam hal tata kelola bank syariah merupakan hal mendesak. Perbankan syariah di Indonesia masih relatif muda usianya. Dengan demikian pembenahan perlu digalakkan sejak dini agar proses operasionalisasi perbankan sesuai dengan prinsip kehati-hatian dan prinsip syariah.

\section{DAFTAR PUSTAKA}

Abedifar, P., P. Molyneux, dan A.Tarazi. 2011. Risk and Stability in Islamic Banking. SSRN eLibrary.

Arunkumar, R., \& Kotreshwar, G. 2005. Risk Management in Commercial Banks (A Case Study of Public and Private Sector Banks). SSRN eLibrary.

Bank Indonesia. 2017. Laporan Perkembangan Perbankan Syariah 2016

2011. Peraturan Bank Indonesia Nomor 13/23/PBI/2011 tentang Penerapan Manajemen Risiko Bagi Bank Umum Syariah dan Unit Usaha Syariah

2009. Peraturan Bank Indonesia Nomor 11/33/PBI/2009 tentang Pelaksanaan Good Corporate Governance Bagi Bank Umum Syariah dan Unit Usaha Syariah

2009. Peraturan Bank Indonesia Nomor 11/3/PBI/2009 tentang Bank Umum Syariah.

Departemen Agama RI. 1993. Al Qur'an dan Terjemahnya. Semarang: CV Alwaah.

Donaldson, Lex dan James H. Davis. 1991. Stewardship Theory or Agency Theory: CEO Governance and Shareholder Returns. Australian Journal of Management 16,1, 49-64.

Grassa, R.. 2009. Islamic Banks' Income Structure and Risk: Evidence from GCC Countries. SSRN eLibrary. 
Greuning, H.V. dan Z. Iqbal. 2011. Analisis Risiko Perbankan Syariah, Alih Bahasa oleh Yulianti Abbas, Jakarta: Salemba Empat.

Iqbal, Z. dan A. Mirakhor. 2007. An Introduction to Islamic Finance, Theory and Practice. Wiley Finance.

Komite Nasional Kebijakan Governance. 2004. Pedoman GCG Perbankan Indonesia. Jakarta.

Komite Nasional Kebijakan Governance. 2006. Pedoman GCG Indonesia. Jakarta.

Lukviarman, Niki. 2016.Corporate Governance. Solo: Era Adicitra Intermedia.

Miller, K.D., dan P. Bromiley. 1990. Strategic Risk and Corporate Performance: An Analysis of Alternative Risk Measures. Academy of Management Journal 33, 4: 756-779.

Misman, F.N. dan M. I. Bhatti. 2010. Risks Exposure In Islamic Banks: A Case Study Of Bank Islam Malaysia Berhad (BIMB), SSRN eLibrary.

Prabowo, Y. 2009. Analisis Resiko dan Pengembalian Hasil pada Perbankan Syariah: Aplikasi Metode VaR dan RAROC pada Bank Syariah Mandiri, Jurnal Ekonomi Islam La Riba, Vol. III No. 1, pp. 90-105.

Rezaee, Z. 2007. Corporate Governance Post Sarbanes Oxley: Regulations, Requirements, and Integrated Processes. New Jersey: John Wiley \& Sons.
Sarker, M. A. A. 1998. Islamic Banking In Bangladesh: Performance, Problems \& Prospects International Journal Of Islamic Financial Services Vol. 1 No.3 